\title{
Exploring Loss and Damage at the International Climate Change Talks
}

\author{
Karen Elizabeth McNamara
}

Published online: 28 August 2014

(c) The Author(s) 2014. This article is published with open access at Springerlink.com

\begin{abstract}
In recent years, there has been a growing need to address loss and damage as a result of climate change through international processes. At the most recent November 2013 international climate change talks in Warsaw, 194 countries negotiated the best way to establish institutional arrangements for loss and damage under the United Nations Framework Convention on Climate Change. Such a decision to establish these arrangements was made in 2012 in Doha in a decision known as the "Doha Gateway." While the 19th (2013) Conference of the Parties succeeded in delivering the Warsaw International Mechanism for Loss and Damage Associated with Climate Change Impacts, there was concern by some negotiators earlier into the conference that this would never transpire given the staunch disagreements between countries and lobbying blocks on a way forward. This article provides a brief historical overview of loss and damage at the climate change talks, and examines the key discourses defining this issue between 2011 and 2013 by analyzing submissions by lobbying blocks and member countries, and final negotiated texts. These discourses revolve around causality and solutions, compensation, and the relationship between loss and damage and adaptation.
\end{abstract}

Keywords Adaptation - Climate change $\cdot$ Loss and damage $\cdot$ Mitigation $\cdot$ United Nations

K. E. McNamara ( $\square)$

School of Geography, Planning and Environmental

Management, The University of Queensland, Brisbane,

QLD 4072, Australia

e-mail: karen.mcnamara@uq.edu.au

\section{A Brief Overview of Loss and Damage}

Held in 1995, the first Conference of the Parties (COP) to the United Nations Framework Convention on Climate Change (hereafter the Convention) focused on preventing climate change and associated impacts through mitigation efforts. This seemed to be logical and straightforward: there was a clear identification of the problem (increased greenhouse gas (GHG) emissions resulting in a changing climate) and solution (mitigate emissions). Unfortunately, wrangling over mitigation commitment targets from member countries has seen delays and sluggish progress in achieving this. By the mid-2000s, adaptation entered the international stage, pushed along even further by the release of the Fourth Assessment Report of the Intergovernmental Panel on Climate Change (IPCC 2007) that made a strong case that mitigation would not prevent all climate change impacts (Ott et al. 2008; Huq et al. 2013). In recent years this shift towards managing the "problem" has magnified. Even if emission trajectories are lowered, adaptation is now an important part of "solving" the climate crisis given current rates of reducing emissions (Pielke et al. 2007; Campbell 2009; Petheram et al. 2010).

Unfortunately, adaptation too, is only part of the collective response needed. In some places, vulnerability to climate change will not be reduced by adaptation strategies-there will be limits to adaptation beyond which strategies cannot deliver acceptable and sustainable outcomes (Adger et al. 2009; Nelson 2011; Dow et al. 2013). Regardless of our collective actions today, there will be irreplaceable losses and acute damages, which is a result of historical and current-day emissions. This was a critical argument made by the Least Developed Countries (LDCs) Group, which represents around one billion people, at the 17th Conference of the Parties (COP17) in 2011 in Durban: 
"GHG emissions that have already been released into the atmosphere will continue to affect the LDCs regardless of changes that we make today" (LDC Group 2011, p. 1).

In an attempt to address these realities, discourses around loss and damage have unfolded at the climate change talks. Despite being more openly discussed at the talks in the last five or so years, its origins can be traced back to the early 1990s when Vanuatu argued that states affected by climate change, particularly sea level rise, must be able to seek compensation for the loss and damage incurred (Warner and Zakieldeen 2011). It took until 2007 at COP13 in Bali for such concern to find its way into a negotiated text at the climate change talks. As outlined in the Bali Action Plan, parties are to support: "Enhanced action on adaptation, including, inter alia, consideration of... (iii) Disaster reduction strategies and means to address loss and damage associated with climate change impacts in developing countries that are particularly vulnerable to the adverse effects of climate change..." (UNFCCC 2007, p. 4). While there was recognition that climate change would cause loss and damage-constituting somewhat of a watershed moment-there was no mention of compensation or liability, which according to Warner and Zakieldeen (2011, p. 3) is language that causes widespread "discomfort for industrialized countries."

Three years later in 2010, COP16 in Cancún was the site of an agreement to a work program on loss and damage under the Subsidiary Body of Implementation. As stipulated in the Cancún Agreements, parties: "Recognize[d] the need to strengthen international cooperation and expertise in order to understand and reduce loss and damage associated with the adverse effects of climate change, including impacts related to extreme weather events and slow onset events" (UNFCCC 2010, p. 6). This was a critical moment in the loss and damage genealogy as it was a compromise reached by both developed and developing countries to move this discussion forward. In the following year (COP17, Durban 2011), negotiators agreed that the work program on loss and damage continue and in particular assess the risk of loss and damage, develop approaches to address such, and consider the role of the Convention in addressing loss and damage. At COP18 in Doha in late 2012, parties agreed that institutional arrangements to address loss and damage as a result of climate change would be firmly established under the Conventiona decision known as the "Doha Gateway" (UNFCCC 2012).

\section{Recent Discourses of Loss and Damage}

The final negotiated texts $(n=3)$ from COP17, COP18, and COP19 (2011-2013) and any written submissions from lobbying blocks $(n=9)$ or member countries $(n=12)$ in this time have all been analyzed for their latent (thematic) content. This analysis explores the tenor and key emergent themes within these texts, as discussed below.

\subsection{Causality and Solutions: Isolating Factors and Focussing on Mitigation}

Submissions made by developed countries from 2011 to 2013 highlighted that loss and damage is caused by a complex mixture of factors. As highlighted by Norway's submission, the impacts of climate change are considered as one of many factors that can result in loss and damage: "Vulnerability to the impacts of climate change is not only caused by climate change... To understand risk and the concept of loss and damage, the drivers of vulnerability must also be considered, such as institutional set up, legislation, social and economic structures, not only the exposure to climate change effects... Loss and damage will be affected by multiple stressors and be the result of the impact of climate change and vulnerability to those impacts, combined with other stressors such as loss of biodiversity and desertification" (Norwegian Government 2011 , p. 2). Such a position gives the impression of protracted responsibility on behalf of developed countries for loss and damage as a result of historical and current emissions. Emphasizing a complex mixture of reasons for loss and damage weakens the concerns raised by developing countries that the impacts of climate change are causing and exacerbating loss and damage.

From 2011 to 2013, developed countries also made submissions at the climate change talks to indicate that mitigation efforts are the primary way to reduce the risks of climate change and avoid much of the loss and damage. Not to underestimate the necessary role of mitigation, such emphasis, however, can have the effect of evading responsibility for loss and damage. As outlined in a submission by Australia back in 2011 (COP17): "meaningful mitigation action by all major emitters remains the primary means of minimising climate-related risks" (Australian Government 2011, p. 2). Placing the onus on mitigation will indeed lessen the burden for communities and places around the world faced with the task of adapting to the impacts of climate change. However, there is no point in placing the onus only on mitigation if countries are not going to work diligently at increasing their emission reduction targets. The net effect of this is that little focus is directed at - and few commitments are being made toboth mitigation and loss and damage.

\subsection{Compensation: A Necessary Component of Loss and Damage?}

Unavoidable loss and damage from the adverse effects of climate change may be addressed through 
risk sharing mechanisms, but total loss and damage from the adverse effects of climate change will need to be redressed through compensation and rehabilitation mechanisms (Government of Ghana 2012, p. 3).

The above statement indicates that loss and damage needs to be addressed through a compensation and rehabilitation fund. This discussion of compensation, as a core way of addressing loss and damage, has long been a contentious subject for parties to agree on. Back in 1991, Vanuatu tabled a compensation proposal that requested an International Insurance Pool to protect small island states who feared loss of territory due to rising sea levels. This Insurance Pool was presented as a collective loss sharing scheme that would compensate those affected. Pushes by other countries and/or lobbying blocks for compensation and related financial contributions have ebbed and flowed over the last few years, with a number of notable examples (Bangladesh, for instance, tabled the need for compensation in 2005 at COP11 and again in 2007 at COP13).

The reemergence of loss and damage discussions at the COPs in recent years has also brought to bear discussions around compensation. The African Group, Alliance of Small Island States (AOSIS), and LDC Group have argued for compensation as a way of addressing uninsurable and unavoidable loss and damage. During COP18, a number of developing countries made strong statements on the role of compensation. They questioned: Who will pay for losses and damages due to climate change? Swaziland, on behalf of the African Group, indicated in a submission that long-term finance in developing countries should include activities such as start-up funds for risk reduction programs, and research and development. They also argued for a "Financial mechanism to provide compensation for residual or unavoidable loss and damage from the adverse effects of climate change and from slow-onset processes," as well as "Ways to address and provide compensation for lost development opportunities" (African Group 2012, p. 4).

Similarly, Nauru, on behalf of AOSIS, recommended that an international mechanism be established with three mutually reinforcing components: insurance; rehabilitation and compensation; and risk management. A number of developing countries and emerging economies from South and Central America and Asia also recommended the: "Establishment of a 'solidarity fund' to provide compensation for residual or unavoidable loss and damage from the adverse effects of climate change from slow-onset processes" (Governments of Bolivia, Ecuador, China, El Salvador, Guatemala, Thailand, Philippines, and Nicaragua 2012 , p. 2). However, developed countries balked at these discussions at COP18 about compensation as a result of historical emissions. This opposition was led by the
American delegation, who argued in their submission at COP18 that an international mechanism: "with an international insurance pool and a compensation/rehabilitation pillar would inhibit a country-driven approach to adaptation... [and] would have to put a monetary value on the lives, livelihoods and assets of the most vulnerable countries and populations" (USA Government 2012, p. 2). This makes the assumption that compensation financing would divert funding away from adaptation activities, which would not be the case if a separate funding stream was established for loss and damage. As a consequence of the vehement opposition of developed countries to the idea of compensation, developing countries "traded off their core demand i.e. compensation" (Shamsuddoha and Bijoy 2013, p. 1). In return, developed countries agreed to examine options for establishing institutional arrangements such as an international mechanism to address loss and damage at COP19.

\subsection{Is Loss and Damage "Beyond" Adaptation?}

With a mandate to establish institutional arrangements at COP19, the G-77 and China (which consists of 132 developing countries including the LDCs and AOSIS) were quick to table a proposal on moving this agenda item forward by proposing an international mechanism. However, this issue was contentious and emotions ran high at COP19. Establishing where the international mechanism might "sit" was another core point of differentiation between key lobbying blocks.

Early on developed countries made it clear that such a mechanism should be subsumed by other institutional arrangements within the Convention such as the Cancún Adaptation Framework, Nairobi Work Programme or Adaptation Committee. Australia's position on this was made clear at COP17: "Australia considers that the work programme under the Cancún Adaptation Framework provides a solid foundation for supporting action on adapting to loss and damage suffered as a result of the adverse impacts of climate change" (Australian Government 2011, p. 1). Norway then reinforced this position at COP19: "approaches to address loss and damage associated with the adverse effects of climate change remains an integrated part of the Cancún Adaptation Framework" (Norwegian Government 2013, p. 1). Other major developed countries were strongly opposed to a separate mechanism and argued for it to be placed under the Cancún Adaptation Framework, or similar existing arrangements in the Convention.

The G-77 and China argued that the new international mechanism on loss and damage should be housed as a separate entity under the Convention itself. A core reason for tabling the need for a separate mechanism was the 
belief that loss and damage was beyond adaptation and thus it was inappropriate for it to sit within the adaptation framework. Likewise, it was considered inappropriate for loss and damage finances to come from adaptation funds, as highlighted by Nauru, on behalf of AOSIS: "Funding for the activities of the international mechanism must be separate from adaptation funding and come from a dedicated source, which should take the form of a separate fund for loss and damage or a special funding window in one of the operating entities of the financial mechanism" (AOSIS 2013, p. 2).

\section{An International Mechanism: Final Remarks}

In the first week of COP19, the G-77 and China tabled a proposal for a loss and damage mechanism as a third separate pillar alongside mitigation and adaptation. The unity on this issue within the G-77 and China was promising. But as the talks progressed into the second weekand the negotiations reached a stage of confidentiality behind closed doors-developing countries became increasingly frustrated at the resistance of developed countries towards a new global body on loss and damage (pers. comm. 2013). The consistent opposition to a new stand-alone mechanism by developed countries reached a climax at 4 a.m. on Wednesday, 20 November when lead negotiators from the G-77 and China walked out of the negotiations (Rowling 2013). Talks resumed but the reluctance of developed countries to support a new body for loss and damage-instead wanting this issue to sit within the existing adaptation framework - still loomed.

Ministers arrived at COP19 during the second week to take hold of the reigns in the negotiations, which eventually delivered an outcome on loss and damage. This came about on Saturday (23 November) as the talks ran overtime. Governments agreed to the "Warsaw international mechanism for loss and damage associated with climate change impacts" but this was a compromised agreement with it remaining under the Cancún Adaptation Framework, rather than becoming a third pillar as insisted by developing countries. The use and positioning of the word under was particularly controversial for the G-77 and China who were opposed to the mechanism being housed under the adaptation framework. Core components of the mechanism include the need to enhance "knowledge and understanding of comprehensive risk management approaches to address loss and damage associated with the adverse effects of climate change", strengthen "dialogue, coordination, coherence and synergies amongst relevant stakeholders", and enhance "action and support, including finance, technology and capacity-building, to address loss and damage associated with the adverse effects of climate change" (UNFCCC 2013, p. 2). The mechanism will be reviewed at COP22 in 2016. Regardless of where it has been "housed" in the interim, the mechanism provides an important step in acknowledging this serious concern with efforts underway to better understand the implications. The critical next step is to realize how best the mechanism can meet the needs of developing countries by using more upto-date information including the recently released Fifth Assessment Report of the Intergovernmental Panel on Climate Change. Only time will tell how the balance of power in the negotiations, and discourses around causality and solutions, compensation, and adaptation, will influence the loss and damage mechanism and result in it being an empty shell or functional pillar at the climate change talks.

Open Access This article is distributed under the terms of the Creative Commons Attribution License which permits any use, distribution, and reproduction in any medium, provided the original author(s) and the source are credited.

\section{References}

Adger, W.N., I. Lorenzoni, and K.L. O’Brien. 2009. Adaptation now. In Adapting to climate change: Thresholds, values, governance, ed. W.N. Adger, I. Lorenzoni, and K.L. O'Brien, 1-22. Cambridge: Cambridge University Press.

African Group. 2012. Submission by the Kingdom of Swaziland on behalf of African Group on work programme on approaches to address loss and damage associated with climate change impacts in developing countries that are particularly vulnerable to the adverse effects of climate change. Submission to Conference of the Parties, Eighteenth session, Doha, 26 November-7 December 2012.

AOSIS (Alliance of Small Island States). 2013. Submission of Nauru on behalf of the Alliance of Small Island States: Views and information on elements of an international mechanism to address loss and damage from the adverse effects of climate change. Submission to Conference of the Parties, Nineteenth session, Warsaw, 11-23 November 2013.

Australian Government. 2011. Submission under the Cancún Agreements, August 2011. Further views and information on the agreed themes of the work programme to consider approaches to address loss and damage associated with climate change impacts in vulnerable developing countries. Submission to Conference of the Parties, Seventeenth session, Durban, 28 November-9 December 2011.

Campbell, J. 2009. Islandness. Shima: The International Journal of Research into Island Cultures 3(1): 85-97.

Dow, K., F. Berkhout, B.L. Preston, R.J.T. Klein, G. Midgley, and M.R. Shaw. 2013. Commentary: Limits to adaptation. Nature Climate Change 3(4): 305-307.

Government of Ghana. 2012. Subsidiary Body on Implementation: Submission of Ghana. Submission to Conference of the Parties, Eighteenth session, Doha, 26 November-7 December 2012.

Governments of Bolivia, Ecuador, China, El Salvador, Guatemala, Thailand, Philippines, and Nicaragua. 2012. UNFCCC-Subsidiary Body of Implementation, Theme III. Submission to Conference of the Parties, Eighteenth session, Doha, 26 November-7 December 2012.

Huq, S., E. Roberts, and A. Fenton. 2013. Commentary: Loss and damage. Nature Climate Change 3: 947-949. 
IPCC (Intergovernmental Panel on Climate Change). 2007. Summary for policymakers. In Climate change 2007: Impacts, adaptation and vulnerability. Contribution of Working Group II to the Fourth Assessment Report of the Intergovernmental Panel on Climate Change, ed. M.L. Parry, O.F. Canziani, J.P. Palutikof, P.J. van der Linden, and C.E. Hanson, 7-22. Cambridge: Cambridge University Press.

LDC (Least Developed Countries) Group. 2011. Loss and damage: Submission by Gambia on behalf of the Least developed Countries Group. Submission to Conference of the Parties, Seventeenth session, Durban, 28 November-9 December 2011.

Nelson, D.R. 2011. Adaptation and resilience: Responding to a changing climate. Wiley Interdisciplinary Reviews-Climate Change 2(1): 113-120.

Norwegian Government. 2011. Submission on approaches to enhance adaptive capacity in developing countries that are particularly vulnerable to the adverse effects of climate change when addressing loss and damage associated with climate change impacts. Submission to Conference of the Parties, Seventeenth session, Durban, 28 November-9 December 2011.

Norwegian Government. 2013. Institutional arrangements under the UNFCCC for approaches to address loss and damage associated with climate change impacts in developing countries that are particularly vulnerable to the adverse effects of climate change to enhance adaptive capacity: Norway. Submission to Conference of the Parties, Nineteenth session, Warsaw, 11-23 November 2013.

Ott, H.E., W. Sterk, and R. Watanabe. 2008. The Bali roadmap: New horizons for global climate policy. Climate Policy 8(1): 91-95.

Petheram, L., K.K. Zander, B.M. Campbell, C. High, and N. Stacey. 2010. Strange changes: Indigenous perspectives of climate change and adaptation in NE Arnhem Land (Australia). Global Environmental Change 20(4): 681-692.

Pielke Jr., R., G. Prins, S. Rayner, and D. Sarewitz. 2007. Climate change 2007: Lifting the taboo on adaptation. Nature 445(7128): 597-598.

Rowling, M. 2013. Climate loss and damage talks in disarray after G77 walks out. Sustainability, Thomson Reuters, 20 November 2013. http://sustainability.thomsonreuters.com/2013/11/20/cli mate-loss-damage-talks-disarray-g77-walks/. Accessed 24 July 2014.
Shamsuddoha, Md., and M.R. Bijoy. 2013. Loss and damage negotiation at the UNFCCC: An era of liability and compensation (Briefing paper). Dhaka: Center for Participatory Research and Development.

UNFCCC (United Nations Framework Convention on Climate Change). 2007. Report of the Conference of the Parties on its thirteenth session, held in Bali from 3 to December 2007, Addendum, Part Two: Action taken by the Conference of the Parties at its thirteenth session. FCCC/CP/2007/6/Add.1.

UNFCCC (United Nations Framework Convention on Climate Change). 2010. Decision 1/CP.16: Report of the Conference of the Parties on its sixteenth session, held in Cancún from 29 November to 10 December 2010, Addendum Part Two: Action taken by the Conference of the Parties at its sixteenth session. FCCC/CP/2010/7/Add.1.

UNFCCC (United Nations Framework Convention on Climate Change). 2012. Approaches to address loss and damage associated with climate change impacts in developing countries that are particularly vulnerable to the adverse effects of climate change to enhance adaptive capacity. Revised proposal by the President. Draft decision -/CP.18. Conference of the Parties, Eighteenth session, Doha, 26 November-7 December 2012. FCCC/CP/2012/L.4/Rev.1.

UNFCCC (United Nations Framework Convention on Climate Change). 2013. Warsaw international mechanism for loss and damage associated with climate change impacts. Decision 2/CP.19. Conference of the Parties, Nineteenth session, Warsaw, 11-23 November 2013.

USA Government. 2012. Submission by the United States of America: The role of the Convention in addressing loss and damage associated with the adverse effects of climate change. Submission to Conference of the Parties, Eighteenth session, Doha, 26 November-7 December 2012.

Warner, K., and S.A. Zakieldeen. 2011. Loss and damage due to climate change: An overview of the UNFCCC negotiations. Oxford: European Capacity Building Initiative. 